Jap. J. Ornithol. 36: 100, 1987

\title{
A Record of Mute Swan Cygnus olor from Eastern Hokkaido
}

\author{
Mark A. BrazIL
}

The status and distribution of the Mute Swan Cygnus olor in Japan is poorly known. The only record of a supposed wild bird was on Hachijo-jima in the Izu lslands in 1933 (OSJ 1974), but in the last decade a feral population has become established in southwest Hokkaido and pairs have been introduced at several famed sightseeing localities throughout Honshu.

The addition of such a large bird to the Japanese avifauna seems to have attracted little interest so far, and as a result records of Mute Swans are scarce. Of those records that do exist it seems that most are for northern Japan, and primarily refer to birds in west Hokkaido-at Onuma Park, Hakodate, and at Utonai-ko, Tomakomai. Several birds have been reported from the Tokachi district (InIMA 1986, FuJimaki in litt), and also from Bibai, Ishikari, and once each from Lake Kussharo and Rausu (FujIMAKI in litt), but so far breeding has only been confirmed at Onuma and at Utonai-ko. With so few records from the eastern part of Hokkaido it is worth noting the following observation.

On 18 July 1987 a pair of Mute Swans was observed at Shirarutoro-ko, Kushiro. They were swimming along the far side of the lake from route 391, staying very close together and keeping close to the edge of the reedbed. They were apparently in wing moult, and had therefore probably spent the summer at the lake. Although watched for sometime using a $20 \mathrm{x}$ fieldscope there was no indication that they had cygnets in attendance. This is the first record of a pair of Mute Swans from the Kushiro district, in fact from Hokkaido east of the Tokachi district. The reed beds and marshes around Shirarutoro-ko are large enough to be occupied by Japanese Crane Grus japonensis and would provide ample nesting habitat for a pair of swans, although it seemed that the pair in question had not bred. Whooper Swan Cygnus cygnus visit the lake regularly in early winter and spring but since the lake freezes over entirely during winter they and other waterfowl there are forced to move on. It would be most interesting to keep a close watch on the area in subsequent summers to see whether or not Mute Swans return and attempt to breed.

Acknowledgements: I would like to thank Dr. Yuzo Fujimaki and Mr. Yoshiaki IuJma for contributing information on Mute Swans in Hokkaido.

Literature Cited. IIImA, Y., 1986. Birds of Taiki. Taiki, published by the author. $\bullet$ OSJ (ORNIthological Society of JAPAN), 1974. Check-list of Japanese birds. 5th ed. Tokyo, Gakushu Kenkyusha.

北海道東部におけるコフハクチョウの紀録．近年，北海道南西部で野生化したコブハクチョウ個体 群が見られ, 石狩, 十勝, 屈斜路湖, 羅曰でる記録はあるが, 繁殖恃大沼とウトナイ沼に限られる. 1987 年 7 月 18 日に, 1 番いが釧路管内シラルトロ湖の西岸沿いを泳いでいた. 翼が換羽中で;お そらくこの湖で夏を過ごしたのであろう。ひなは連れていなかったが，十勝より東に拈ける番いの初 記録である. シラルトロ湖周辺のヨシ原は十分な広さがあり, 観察を続ければ繁殖の有無が確認され よう. 一マーク・ブラジル。

Author's address: 28 St. John's Well Court, St.John's Well Lane, Berkhamsted, Hertfordshire HP $41 \mathrm{JQ}, U K$. イギリス・ハートフォードシャー・バーカムステッド. 